\title{
Cost of care of chronic non-communicable diseases in Jamaican patients: the role of obesity
}

\author{
Christine M. Fray-Aiken ${ }^{1}$, Rainford J. Wilks² ${ }^{2}$ Abdullahi O. Abdulkadri ${ }^{3}$, \\ Affette M. McCaw-Binns ${ }^{4}$ \\ College of Health Sciences, University of Technology, Jamaica \\ Tropical Medical Research Institute, University of the West Indies, Kingston, Jamaica \\ Department of Economics, University of the West Indies, Kingston, Jamaica \\ 4 Department of Community Health and Psychiatry, University of the West Indies, Kingston, Jamaica
}

\begin{abstract}
OBJECTIVE: To estimate the economic cost of Chronic Non-Communicable Diseases (CNCDs) and the portion attributable to obesity among patients in Jamaica.

METHODS: The cost-of-illness approach was used to estimate the cost of care in a hospital setting in Jamaica for type 2 diabetes mellitus, hypertension, coronary heart disease, stroke, gallbladder disease, breast cancer, colon cancer, osteoarthritis, and high cholesterol. Cost and service utilization data were collected from the hospital records of all patients with these diseases who visited the University Hospital of the West Indies (UHWI) during 2006. Patients were included in the study if they were between 15 and 74 years of age and if female, were not pregnant during that year. Costs were categorized as direct or indirect. Direct costs included costs for prescription drugs, consultation visits (emergency and clinic visits), hospitalizations, allied health services, diagnostic and treatment procedures. Indirect costs included costs attributed to premature mortality, disability (permanent and temporary), and absenteeism. Indirect costs were discounted at $3 \%$ rate.

RESULTS: The sample consisted of 554 patients (40\%) males $(60 \%)$ females. The economic burden of the nine diseases was estimated at US\$ 5,672,618 (males $37 \%$; females $63 \%$ ) and the portion attributable to obesity amounted to US\$ 1,157,173 (males 23\%; females 77\%). Total direct cost was estimated at US\$ 3,740,377 with female patients accounting for $69.9 \%$ of this cost. Total indirect cost was estimated at US\$1,932,241 with female patients accounting for $50.6 \%$ of this cost. The greater cost among women was not found to be statistically significant. Overall, on a per capita basis, males and females accrued similar costs-of-illness (US\$ 9,451.75 vs. US\$ 10,758.18).

CONCLUSIONS: In a country with per capita GDP of less than US\$ 5,300, a per capita annual cost of illness of US\$ 10,239 for CNCDs is excessive and has detrimental implications for the health and development of Jamaica.
\end{abstract}

\section{Keywords}

Chronic non-communicable diseases; Obesity; Cost-of-illness

\section{INTRODUCTION}

The prevalence of obesity in Jamaica has been increasing over the last fifty years resulting in the main public health concern changing from a high prevalence of undernutrition and infectious diseases to a high prevalence of obesity and chronic non-communicable diseases (CNCDs). Obesity is known to be associated with several chronic diseases (including diabetes, hypertension and their sequelae) and early mortality. As a result, obesity and its associated diseases are likely to contribute significantly to health care costs burden in the Jamaican society due to increased morbidity and premature mortality. Esti- mating health costs associated with obesity will inform and strengthen the argument for effective intervention to reduce this burden in Jamaica.

With economic development comes the public health transition mentioned above [1-3]. Many mid- to low-income countries undergoing this transition will at the same time manifest significant burden from both groups of diseases. In such countries, as life expectancies have increased, more persons survive, living long enough to be afflicted with CNCDs that result from unhealthy diets, obesity, low levels of physical activity as well as other risk factors. At the same time, segments of
Corresponding author Christine Fray-Aiken caiken@utech.edu.jm

\section{Disclosure}

The authors have no conflicts of interest to declare. 
the population are still dealing with the traditional risks to health including unsafe water, under-nutrition and poor sanitation [2-4].

Jamaica has been undergoing the epidemiological transition described above [5]. More than half of Jamaicans are overweight or obese [5] and both overweight and obesity are associated with several comorbidities $[6,7]$. According to Bray et al. [8], there are two physiological categories into which each disease with an increased risk as a result of the presence of overweight can be classified. The first category of disabilities is due to the physical presence of corpulence. Psychosocial function, osteoarthritis and sleep apnea belong in this category. The second category of disabilities results from the metabolic changes associated with overweight (e.g., diabetes mellitus, gallbladder disease, hypertension, cardiovascular disease, and certain cancers [8]). Also the incidence of several chronic diseases increase with degree of overweight $[6,7,9]$. Several studies show an association between overweight/obesity and CNCDs, e.g., diabetes mellitus [10-16], gallbladder disease $[17,18]$, hypertension [10,19-21], coronary heart disease [22-25], stroke [26-32], and serum triglyceride levels [33,34].

Seventy percent of Jamaican women and $20 \%$ of Jamaican men have high waist circumferences (WC) [5]. Also, 70\% of Jamaican women and $9 \%$ of Jamaican men have high waist-to-hip ratios (WHR) [5]. Both are associated with increased cardiovascular risk [22-24,35]. Therefore, estimating the impact of obesity is via the burden of chronic noncommunicable diseases for which obesity is a major risk factor is well-founded. Especially since seven of the 10 leading causes of mortality in Jamaica in 1998 were CNCDs [36]. For Jamaica in 2001, the total economic burden of diabetes and hypertension amounted to J\$ 10.18 billion (US\$ 221 million at 2001 exchange rates) and J\$ 12.26 billion (US\$ 266 million at 2001 exchange rates) respectively [37]. Given that obesity is a risk factor for both diabetes and hypertension, obesity is therefore a significant burden on the Jamaican economy.

The foregoing suggests that $\mathrm{CNCDs}$ constitute an important disease burden to the Jamaican Health Sector and significant economic burden to the country. This epidemiological/ economic transition is leading to increased prevalence of CNCDs, requiring more health care and increasing costs. These growing costs are unsustainable and if left unchecked could reverse health gains and hinder economic growth. To obtain a greater insight into this subject, a case study of the University
Hospital of the West Indies (UHWI) was done. There are several studies that estimate the cost of obesity [38-40]. Those studies for the most part, used prevalence data, while this study estimated the economic burden of nine CNCDs using data from hospital records.

This study aimed to estimate the economic burden of obesity and related chronic noncommunicable diseases among patients in Jamaica. Health care in Jamaica is provided through a combination of public, private and quasi-public sector hospitals and healthcare facilities. The UHWI is the largest hospital in Jamaica and serves as a regional referral hospital. Therefore, patients who visited the UHWI during 2006 were deemed most suitable for this study. Data from hospital records of patients who visited UHWI during 2006 were analysed to estimate the economic burden of CNCDs. These estimations would provide important information for policy development, program planning and resource allocation in relation to CNCD management. In addition, the knowledge obtained will be useful as a benchmark of the economic cost of obesity in Jamaica and as a point of reference in the estimation of the economic burden of disease. Actual use of medical services were used to estimate the monetary value of that burden in order to strengthen our argument for intervention and guide policy makers.

\section{METHODS}

\section{Design of the study}

This is a prevalence-based cost-of-illness evaluation study using a survey of patient records and data from secondary sources. Primary data including cost and service utilization data were collected from the hospital records of patients. Secondary data included prevalence data from local [5] and other sources $[6,41]$ which were used to calculate the population attributable risk of obesity.

\section{Setting}

Study subjects included all adult patients who visited the University Hospital of the West Indies as a result of type 2 diabetes, hypertension, coronary heart disease, stroke, gallbladder disease, breast cancer, colon cancer, osteoarthritis, and high cholesterol during 2006, and who were 15-74 years old and if female, did not give birth during the reference year. The age-range of 15-74 years was chosen because it represents approximately $70 \%$ of the Jamaican population [42] and captures predominantly the economically active population. 
Medical records were used to calculate actual costs of medical care to each patient as a result of type 2 diabetes, hypertension, coronary heart disease, stroke, gallbladder disease, breast cancer, colon cancer, osteoarthritis, and high cholesterol. The human capital approach was used to calculate the cost-ofillness due to mortality and morbidity. Costof-illness calculations were divided into two types: direct costs and indirect costs. Direct costs included costs of drugs, consultations and hospitalizations, while indirect costs included costs attributed to morbidity, and premature mortality.

\section{Direct costs}

\section{Drugs}

The hospital records were used to generate the list of drugs prescribed to patients to manage their conditions. The usual customary and reasonable (UCR) costs suggested by pharmacies were then applied to calculate costs of drugs needed for each disease condition by multiplying the unit cost of each drug prescribed by the dosage. This gave an estimate of the amount spent on each drug for the year. The total amount spent on drugs in 2006 was determined by summing these products across all drugs.

\section{Consultations}

Consultation costs were calculated from ambulatory patients whether or not they were hospitalized at any point throughout the year. The total number of visits was multiplied by the cost of a clinic visit to arrive at the cost of consultation for each patient. The addition of the individual costs of consultation represented the total costs of consultation.

\section{Hospitalizations}

Hospitalization costs consisted of charges for medications used during hospitalization and investigative and therapeutic procedures done. These charges were retrieved from the medical records of patients and summed up to get the total cost of hospitalization in 2006.

\section{Allied Health Services, diagnostic and treatment procedures}

Records of allied health services, medical tests and other laboratory procedures, and treatment procedures carried as outpatient services were used to ascertain the types of services utilized and procedures done and their frequencies. The unit cost of each service/procedure for 2006 was obtained from the hospital's assessment office. The total cost of each service/procedure was determined as the product of its unit cost and the total number of times the service/procedure was done in 2006. The total costs of the allied he- alth services, diagnostic procedures, and treatment procedures for 2006 were determined by summing the cost of individual items in each category.

\section{Indirect costs}

\section{Premature mortality}

Data on mortality resulting from each comorbidity were obtained from the hospital database and the number of Years of Productive Life Lost in employed patients due to premature mortality $\left(\mathrm{YPLL}_{\mathrm{M}}\right.$ ) associated with each comorbidity was calculated based on the life expectancy for males and females in Jamaica as reported by the World Health Organization (WHO). A 3\% discount rate was applied to the YPLL to convert future earnings to current value $[43,44]$. The cost was then calculated by multiplying YPLL by annual per capita GNP.

$$
Y P L L_{M}=\frac{N}{r}\left(1-e^{-r L}\right)
$$

Where $\mathrm{N}=$ number of deaths; $\mathrm{L}=$ standard life expectancy at age of death (years), and $r=$ discount rate

\section{Disability}

\section{Permanent Disability}

The number of years lost due to permanent disability before the age of 65 years was also calculated. This is the number of $\mathrm{YPLL}_{\mathrm{D}}$. The patients were divided into age groups and $\mathrm{YPLL}_{\mathrm{D}}$ due to permanent disability was calculated by multiplying the number of patients in each age group by the difference between the age limit of 65 years and the median of the age group as shown in the equation below [45]:

$$
Y P L L_{D}=\sum_{i=1}^{L}\left[(L-i) \times d_{i}\right]
$$

Where $\mathrm{I}=$ lower age limit established (median age), $\mathrm{L}=$ upper age limit established (65 years), $\mathrm{i}=$ median age at beginning of permanent disability, and $d_{i}=$ number of patients with permanent disability at age i.

A 3\% discount rate was then applied to calculate the number of discounted YPLL due to permanent disability. The cost of permanent disability was then estimated by multiplying the annual per capita GNP by YPLL $_{D}$.

\section{Temporary Disability}

The number of years lost due to temporary disability $\left(\mathrm{YPLL}_{\mathrm{T}}\right.$ ) before the age of 65 years was calculated from the number of disability days for patients who did not have a permanent disability. A 3\% discount rate was then applied to calculate the number of discounted YPLL ${ }_{\text {. }}$. The cost of temporary disability was then estimated by multiplying the annual per capita GNP by the number of YPLL . Where the period of temporary disability was less 
than one year, discounting did not apply. In such cases, the fraction of year of disability was simply calculated by dividing the number of disability days by 365 .

\section{Absenteeism}

The number of absent days for employed patients was estimated as the sum of the number of days spent in consultation, in hospitalization and on sick leave from work. Thus, sick leave days were underestimated as this information was not always recorded in the clinical files. Lost salaries were then estimated. The first step was separating the employed patients according to the International Standard Classification of Occupations 2008 (ISCO-08) [46]. The major groups of the classification were: managers, professionals, technicians and associate professionals, clerical support workers, service and sales workers, skilled agricultural, forestry and fishery workers, craft and related trades workers, plant and machine operators, and assemblers, elementary occupations, and armed forces occupations [46]. The next step was to obtain the daily salaries of each category from national databases $[47,48]$. The salaries were then converted to U.S. dollars at 2006 US average annual rate of exchange. The costof-illness due to absenteeism was calculated as the product of the number of days absent and the daily salaries [49].

\section{Cost of obesity}

The economic burden of obesity was then estimated from the calculated direct and indirect costs of type 2 diabetes, hypertension, coronary heart disease, stroke, gallbladder disease, breast cancer, colon cancer, osteoarthritis, and high cholesterol. The analysis of the proportion of the cost of each case which was attributable to obesity was based on the population attributable risk of obesity. The population attributable risk (PAR) is also referred to as the "etiologic fraction" or "population attributable fraction". It is a measure of the proportion of cases of a given disease (e.g., type 2 diabetes) that is due to a risk factor of interest (e.g., obesity). The population attributable risk of obesity was applied to the direct and indirect costs of each of the disease. The sum of the costs gave an estimate of the economic burden of obesity. There are several studies that support the use of PAR for the estimation of the fraction of a disease that is attributable to obesity [50-53].

$$
P A R=\frac{P(R R-1)}{P(R R-1)+1}
$$

Where PAR = population attributable risk, $\mathrm{RR}=$ relative risk (estimated by the odds ratio, $\mathrm{OR}$ ), and $\mathrm{P}=$ prevalence rate of disease/mortality.
However in order to estimate the PAR, the relative risk of each obesity comorbidity was obtained from other studies.

Since relative risks were not available for Jamaica on all of the comorbidities of interest (except for diabetes mellitus, hypertension and high cholesterol), relative risks for the remaining comorbidities were obtained from studies from other countries. In order to decide which source(s) of relative risks to use, the relative risks obtained were compared with those available for Jamaica. The countries for which relative risks could be found that were comparable with those available for Jamaica were used as the sources for the other relative risk values (Table I).

The PAR for obesity and the $95 \%$ confidence intervals (CIs) were then computed for each comorbidity. The PAR for each of the 9 comorbidities studied was multiplied by the cost of the corresponding comorbidity and then summed to represent the corresponding estimate of the cost of obesity. A sensitivity analysis was also done on both the estimated costs and the PARs to provide a range of values for the cost estimates.

\section{Sensitivity analysis}

One-way sensitivity analyses was performed to assess the robustness of the total cost estimates. In a one-way sensitivity analysis, the value of one variable is changed at a time in the estimation of cost, and the impact that the change has on the results examined. In this study, the cost of illness was estimated at the $3 \%$ discount rate. It was then analyzed at $95 \%$ and $97.5 \%$ confidence intervals for the population attributable risks for obesity.

\section{RESULTS}

All 554 patients (except females who gave birth during 2006) between the ages of 15-74 years of age who visited the hospital during 2006 for the diseases being studied were included in the study. The mean age was 56.9 years. Of the patients studied, $220(40 \%)$ were males and 334 (60\%) were females.

\section{Direct costs \\ Drugs}

The total cost of prescription drugs was US\$ 2,245,245.10, averaging US\$ 4,052.79 per patient during 2006. The greatest proportion of the payment was on drugs for the management of diabetes mellitus (US\$ 1,531,885.30; $68.2 \%)$, followed by coronary heart disease (US\$2 296,634.72; 13.2\%), hypertension (US\$ $186,821.16 ; 8.3 \%$ ) and breast cancer (US\$ $75,246.04 ; 3.4 \%)$. The least amount spent on drugs was for gallbladder disease (US\$ 6.90) 


\begin{tabular}{|c|c|c|c|c|c|c|}
\hline \multirow{2}{*}{ Disease } & \multicolumn{2}{|c|}{ RR (95\%Cl) } & \multicolumn{2}{|c|}{ PAR [\% (95\%Cl)] } & \multicolumn{2}{|c|}{ PAR [\% (97.5\%Cl)] } \\
\hline & Males & Females & Males & Females & Males & Females \\
\hline DM [7] & $\begin{array}{c}2.05 \\
(1.20-3.49)\end{array}$ & $\begin{array}{c}2.14 \\
(1.32-3.47)\end{array}$ & $\begin{array}{c}0.11 \\
(0.0687-0.151)\end{array}$ & $\begin{array}{c}0.30 \\
(0.259-0.341)\end{array}$ & $\begin{array}{c}0.11 \\
(0.0625-0.157)\end{array}$ & $\begin{array}{c}0.30 \\
(0.253-0.347)\end{array}$ \\
\hline HTN [7] & $\begin{array}{c}2.36 \\
(1.47-3.78)\end{array}$ & $\begin{array}{c}2.76 \\
(1.85-4.11)\end{array}$ & $\begin{array}{c}0.14 \\
(0.0989-0.181)\end{array}$ & $\begin{array}{c}0.40 \\
(0.359-0.441)\end{array}$ & $\begin{array}{c}0.14 \\
(0.0928-0.187)\end{array}$ & $\begin{array}{c}0.40 \\
(0.353-0.447)\end{array}$ \\
\hline CHD [43] & $\begin{array}{c}1.40 \\
(1.17-1.68)\end{array}$ & $\begin{array}{c}1.32 \\
(1.07-1.62)\end{array}$ & $\begin{array}{c}0.05 \\
\left(8.40 \times 10^{-3}-0.0916\right)\end{array}$ & $\begin{array}{c}0.11 \\
(0.0684-0.152)\end{array}$ & $\begin{array}{c}0.05 \\
\left(2.24 \times 10^{-3}-0.0978\right)\end{array}$ & $\begin{array}{c}0.11 \\
(0.0622-0.158)\end{array}$ \\
\hline \multicolumn{7}{|l|}{$\mathbf{S}[8]$} \\
\hline - Overweight & $\begin{array}{c}1.23 \\
(1.13-1.34)\end{array}$ & $\begin{array}{c}1.15 \\
(1.00-1.32)\end{array}$ & $\begin{array}{c}0.03 \\
(0.0116-0.0716)\end{array}$ & $\begin{array}{c}0.05 \\
(0.0488-0.0512)\end{array}$ & $\begin{array}{c}0.03 \\
(0.0177-0.0777)\end{array}$ & $\begin{array}{c}0.05 \\
(0.0486-0.0514)\end{array}$ \\
\hline - Obesity & $\begin{array}{c}1.51 \\
(1.33-1.72)\end{array}$ & $\begin{array}{c}1.49 \\
(1.27-1.74)\end{array}$ & $\begin{array}{c}0.06 \\
(0.0184-0.1016)\end{array}$ & $\begin{array}{c}0.16 \\
(0.118-0.202)\end{array}$ & $\begin{array}{c}0.06 \\
(0.0123-0.1077)\end{array}$ & $\begin{array}{c}0.16 \\
(0.112-0.2077)\end{array}$ \\
\hline \multicolumn{7}{|l|}{ GD [8] } \\
\hline - Overweight & $\begin{array}{c}1.09 \\
(0.87-1.37)\end{array}$ & $\begin{array}{c}1.44 \\
(1.05-1.98)\end{array}$ & $\begin{array}{c}0.01 \\
(-0.0292-0.0492)\end{array}$ & $\begin{array}{c}0.14 \\
(0.100-0.179)\end{array}$ & $\begin{array}{c}0.01 \\
(-0.0349-0.0549)\end{array}$ & $\begin{array}{c}0.14 \\
(0.0951-0.185)\end{array}$ \\
\hline - Obesity & $\begin{array}{c}1.43 \\
(1.04-1.96)\end{array}$ & $\begin{array}{c}2.32 \\
(1.17-4.57)\end{array}$ & $\begin{array}{c}0.05 \\
(0.01084-0.0892)\end{array}$ & $\begin{array}{c}0.33 \\
(0.291-0.369)\end{array}$ & $\begin{array}{c}0.05 \\
\left(5.05 \times 10^{-3}-0.0949\right)\end{array}$ & $\begin{array}{c}0.33 \\
(0.285-0.375)\end{array}$ \\
\hline \multicolumn{7}{|l|}{ BC [8] } \\
\hline Overweight & - & $\begin{array}{c}1.08 \\
(1.03-1.14)\end{array}$ & & $\begin{array}{c}0.03 \\
(0.0265-0.0335)\end{array}$ & & $\begin{array}{c}0.03 \\
(0.0259-0.0341)\end{array}$ \\
\hline Obesity & - & $\begin{array}{c}1.13 \\
(1.05-1.22)\end{array}$ & & $\begin{array}{c}0.05 \\
(0.0333-0.133)\end{array}$ & & $\begin{array}{c}0.05 \\
(0.0456-0.146)\end{array}$ \\
\hline \multicolumn{7}{|l|}{ CC [8] } \\
\hline - Overweight & $\begin{array}{c}1.51 \\
(1.37-1.67)\end{array}$ & $\begin{array}{c}1.45 \\
(1.30-1.62)\end{array}$ & $\begin{array}{c}0.06 \\
(0.0200-0.100)\end{array}$ & $\begin{array}{c}0.15 \\
(0.110-0.190)\end{array}$ & $\begin{array}{c}0.06 \\
(0.0141-0.1059)\end{array}$ & $\begin{array}{c}0.15 \\
(0.1041-0.196)\end{array}$ \\
\hline - Obesity & $\begin{array}{c}1.95 \\
(1.59-2.39)\end{array}$ & $\begin{array}{c}1.66 \\
(1.52-1.81)\end{array}$ & $\begin{array}{c}0.10 \\
(0.0600-0.140)\end{array}$ & $\begin{array}{c}0.20 \\
(0.160-0.240)\end{array}$ & $\begin{array}{c}0.10 \\
(0.0541-0.146)\end{array}$ & $\begin{array}{c}0.20 \\
(0.154-0.246)\end{array}$ \\
\hline \multicolumn{7}{|l|}{ OA [8] } \\
\hline Overweight & $\begin{array}{c}2.76 \\
(2.05-3.70)\end{array}$ & $\begin{array}{c}1.80 \\
(1.75-1.85)\end{array}$ & $\begin{array}{c}0.17 \\
(0.144-0.196)\end{array}$ & $\begin{array}{c}0.23 \\
(0.204-0.256)\end{array}$ & $\begin{array}{c}0.17 \\
(0.140-0.200)\end{array}$ & $\begin{array}{c}0.23 \\
(0.200-0.260)\end{array}$ \\
\hline Obesity & $\begin{array}{c}4.20 \\
(2.76-6.41)\end{array}$ & $\begin{array}{c}1.96 \\
(1.88-2.04)\end{array}$ & $\begin{array}{c}0.28 \\
(0.254-0.306)\end{array}$ & $\begin{array}{c}0.27 \\
(0.254-0.296)\end{array}$ & $\begin{array}{c}0.28 \\
(0.250-0.310)\end{array}$ & $\begin{array}{c}0.27 \\
(0.240-0.300)\end{array}$ \\
\hline HC [7] & $\begin{array}{c}2.89 \\
(2.04-4.10)\end{array}$ & $\begin{array}{c}3.57 \\
(1.91-6.68)\end{array}$ & $\begin{array}{c}0.18 \\
(0.139-0.221)\end{array}$ & $\begin{array}{c}0.49 \\
(0.449-0.531)\end{array}$ & $\begin{array}{c}0.18 \\
(0.133-0.227)\end{array}$ & $\begin{array}{c}0.49 \\
(0.443-0.537)\end{array}$ \\
\hline $\begin{array}{l}\text { Obesity } \\
\text { prevalence } \\
\text { (\%) }[7]\end{array}$ & 12 & 38 & - & - & - & - \\
\hline
\end{tabular}

Table I. Relative Risk (RR) due to obesity and Population Attributable Risk (PAR) due to obesity for the diseases studied $\mathrm{BC}=$ Breast Cancer, $\mathrm{CC}=$ Colon Cancer, $\mathrm{CHD}=$ Coronary Heart Disease, $\mathrm{DM}=$ Diabetes Mellitus, $\mathrm{GD}=$ Gallbladder Disease, $\mathrm{HC}=$ High Cholesterol, $\mathrm{HTN}=$ hypertension, $\mathrm{OA}=$ osteoarthritis, $\mathrm{S}=$ Stroke

which accounted for $<0.01 \%$ of the total amount spent on drugs by patients (Table II). Women accounted for about $62 \%$ of the overall cost of drug therapy. This amounted to US\$ $1,388,280.79$. Being a woman was not found to be statistically associated with greater drug costs $(p=0.63 ; \mathrm{CI}=95 \%)$. The average costs per males and females were US\$ $3,895.29$ and US\$ 4,156.53 respectively.

Payment on drugs accounted for a major proportion of the cost of treatment. For high cholesterol, approximately $100 \%$ of the total expenditure for treatment was on drugs. In addition, the proportion of the cost of treatment that was due to drug cost expenditure was at least about half of the cost or greater for diabetes mellitus (89\%), hypertension $(66 \%)$, stroke $(64 \%)$, coronary heart disease (61\%), and osteoarthritis (49\%). The diseases for which drugs contributed the least towards total overall treatment were colon cancer and gallbladder disease at $6 \%$ and $0.1 \%$ respectively (Table III).

\section{Consultations}

The total cost of consultations (out-patient + emergency visits) for 2006 for these patients was US\$23,811.20. Females accounted for $72.6 \%$ of this cost, however, women were not found to have statistically higher consultations costs $(\mathrm{P}$-value $=0.17 ; \mathrm{CI}=95 \%)$ (Table II). Breast cancer, diabetes mellitus, hypertension, and coronary heart disease ac- 
counted for the greater proportion of the overall consultation cost: US\$ 6,920.13 (29.1\%); US\$6,218.55 (26.1\%); US\$ 4,188.22(17.6\%) and US\$ 4,007.51 (16.8\%) respectively (Table II).
Females accounted for $61.3 \%$ of the cost of consultations when the cost of breast cancer was removed from the results. Again, women were not found to have statistically greater consultations costs even without the inclusion

\begin{tabular}{|c|c|c|c|c|c|c|c|}
\hline & $\begin{array}{l}\text { Prescription } \\
\text { drugs (US\$) }\end{array}$ & $\begin{array}{c}\text { Consultation } \\
\text { (US\$) }\end{array}$ & $\begin{array}{l}\text { Drugs used } \\
\text { during hospita- } \\
\text { lization (US\$) }\end{array}$ & $\begin{array}{l}\text { Allied health } \\
\text { services } \\
\text { (US\$) }\end{array}$ & $\begin{array}{l}\text { Diagnostic } \\
\text { services } \\
\text { (US\$) }\end{array}$ & $\begin{array}{l}\text { Treatment } \\
\text { services } \\
\text { (US\$) }\end{array}$ & $\begin{array}{l}\text { Total direct cost } \\
\text { [US\$ (\%)] }\end{array}$ \\
\hline \multicolumn{8}{|l|}{ DM } \\
\hline - Males & $575,149.75$ & $2,636.67$ & $6,673.64$ & 242.83 & $10,323.33$ & $47,927.19$ & $642,953.41(37.5)$ \\
\hline - Females & $956,735.55$ & $3,581.88$ & $12,634.53$ & 537.25 & $35,221.25$ & $62,950.40$ & $1,071,660.86(62.5)$ \\
\hline - Total & $1,531,885.30$ & $6,218.55$ & $19,308.17$ & 780.08 & $45,544.58$ & $110,877.59$ & $1,714,614.27(100)$ \\
\hline \multicolumn{8}{|l|}{ HTN } \\
\hline - Males & $87,293.87$ & $1,604.09$ & $1,783.50$ & $7,719.62$ & $24,220.18$ & $6,613.51$ & $129,234.77(45.7)$ \\
\hline - Female & $99,527.29$ & $2,584.13$ & $2,193.63$ & 801.41 & $43,242.60$ & $5,065.25$ & $153,414.31(54.3)$ \\
\hline - Total & $186,821.16$ & $4,188.22$ & $3,977.13$ & $8,521.03$ & $67,462.78$ & $11,678.76$ & $282,649.08(100)$ \\
\hline \multicolumn{8}{|l|}{ CHD } \\
\hline - Males & $135,802.18$ & $1,518.85$ & $2,778.74$ & 443.18 & $28,166.29$ & $84,743.50$ & $253,452.74(52.1)$ \\
\hline - Females & $160,832.54$ & $2,488.66$ & $4,738.14$ & 270.16 & $40,655.74$ & $24,337.84$ & $233,323.08$ (47.9) \\
\hline • Total & $296,634.72$ & $4,007.51$ & $7,516.88$ & 713.34 & $68,822.03$ & $109,081.34$ & $486,775.82(100)$ \\
\hline \multicolumn{8}{|l|}{$\mathbf{s}$} \\
\hline - Males & $26,079.27$ & 393.10 & 851.76 & 267.09 & $9,876.49$ & 601.10 & $38,068.81(46.2)$ \\
\hline - Females & $26,546.44$ & 521.08 & $2,212.09$ & 421.87 & $14,361.64$ & 337.00 & $44,400.12(53.8)$ \\
\hline - Total & $52,625.71$ & 914.18 & $3,063.85$ & 688.96 & $24,238.13$ & 938.10 & $82,468.93(100)$ \\
\hline \multicolumn{8}{|l|}{ GD } \\
\hline - Males & 0.00 & 42.48 & 0.00 & 0.00 & 721.77 & 0.00 & $764.25(7.1)$ \\
\hline - Females & 6.90 & 244.53 & 407.60 & 18.21 & $1,838.51$ & $7,554.34$ & $10,070.09(92.9)$ \\
\hline - Total & 6.90 & 287.01 & 407.60 & 18.21 & $2,560.28$ & $7,554.34$ & $10,834.34(100)$ \\
\hline \multicolumn{8}{|l|}{ BC } \\
\hline - Males & 0.00 & 0.00 & 0.00 & 0.00 & 0.00 & 0.00 & $0.00(0)$ \\
\hline - Females & $75,246.04$ & $6,920.13$ & $2,595.82$ & 124.44 & $96,134.23$ & $771,977.99$ & $952,998.65(100)$ \\
\hline - Total & $75,246.04$ & $6,920.13$ & $2,595.82$ & 124.44 & $96,134.23$ & $771,977.99$ & $952,998.65(100)$ \\
\hline \multicolumn{8}{|l|}{ CC } \\
\hline - Males & 66.12 & 180.75 & 173.11 & 27.32 & $3,840.33$ & $14,875.73$ & $19,163.36(33.2)$ \\
\hline - Females & $3,577.98$ & 372.01 & 329.68 & 6.07 & $3,983.75$ & $30,366.08$ & $38,635.57(66.8)$ \\
\hline - Total & $3,644.10$ & 552.76 & 502.79 & 33.39 & $7,824.08$ & $45,241.81$ & $57,798.93(100)$ \\
\hline \multicolumn{8}{|l|}{ OA } \\
\hline - Males & $11,799.03$ & 127.24 & 0.18 & 36.42 & 165.41 & $7,554.34$ & 19,682.62 (18.8) \\
\hline - Females & $39,256.69$ & 542.45 & 88.06 & 133.54 & 894.83 & $44,237.91$ & $85,153.48(81.2)$ \\
\hline - Total & $51,055.72$ & 669.69 & 88.24 & 169.96 & $1,060.24$ & $51,792.25$ & $104,836.10(100)$ \\
\hline \multicolumn{8}{|l|}{$\mathrm{HC}$} \\
\hline - Males & $20,774.09$ & 31.89 & 7.12 & 0.00 & 0.00 & 0.00 & $20,813.10(43.9)$ \\
\hline - Females & $26,551.36$ & 21.26 & 0.00 & 0.00 & 15.18 & 0.00 & $26,587.80(56.1)$ \\
\hline • Total & $47,325.45$ & 53.15 & 7.12 & 0.00 & 15.18 & 0.00 & $47,400.90(100)$ \\
\hline \multicolumn{8}{|c|}{ Economic burden } \\
\hline - Males & $856,964.31$ & $6,535.07$ & $12,268.05$ & $8,736.46$ & $77,313.80$ & $162,315.37$ & $1,124,133.06(30.1)$ \\
\hline - Females & $1,388,280.79$ & $17,276.13$ & $25,199.55$ & $2,312.95$ & $236,347.73$ & $946,826.81$ & $2,616,243.96(69.9)$ \\
\hline - Total & $2,245,245.10$ & $23,811.20$ & $37,467.60$ & $11,049.41$ & $313,661.53$ & $1,109,142.18$ & $3,740,377.02(100)$ \\
\hline
\end{tabular}

Table II. Breakdown of the total direct costs of the diseases studied by gender (US $\$$ )

$\mathrm{BC}=$ Breast Cancer, $\mathrm{CC}=$ Colon Cancer, $\mathrm{CHD}=$ Coronary Heart Disease, $\mathrm{DM}=$ Diabetes Mellitus, $\mathrm{GD}=$ Gallbladder Disease, $\mathrm{HC}=$ High Cholesterol, HTN = hypertension, $\mathrm{OA}=$ osteoarthritis, $\mathrm{S}=$ Stroke 


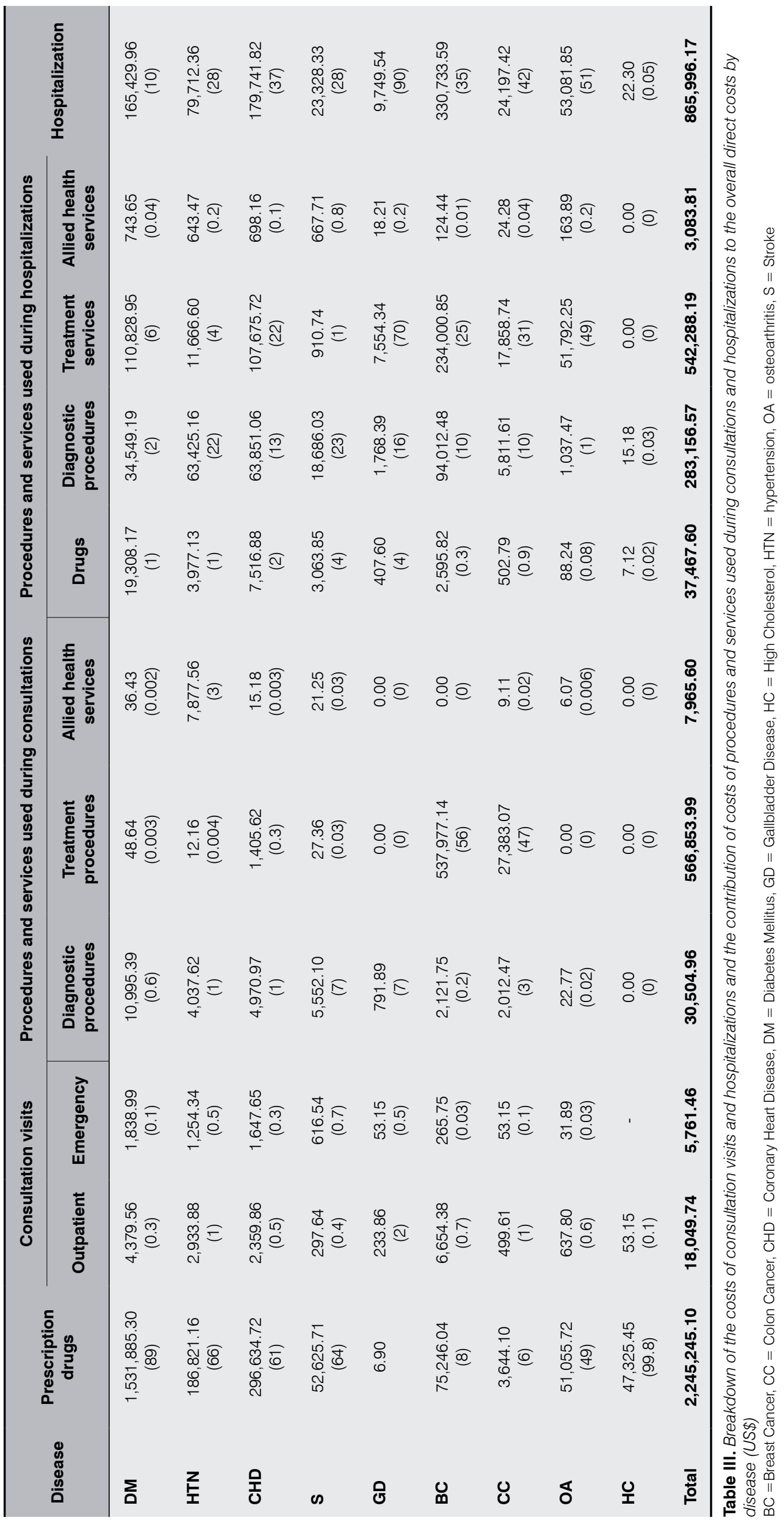


of breast cancer cost $(\mathrm{p}=0.44 ; \mathrm{CI}=95 \%)$. Outpatient consultations accounted for $75.8 \%$ of the overall cost of consultations (Table III).

\section{Hospitalization}

The greatest cost accrued during hospitalizations was for breast cancer at US\$330,758.56, followed by coronary heart disease, diabetes mellitus, and hypertension at US\$179,741.83; US\$ 162,124.54, and US\$ 79,712.36, respectively (Table II). With respect to the procedures and services used during hospitalization, the greatest contributors were treatment services at US\$ 542,288.19 and diagnostic procedures at US\$ 283,156.57 (Table III).

\section{Allied health services}

The total cost of allied health services (e.g., dietician visit and physiotherapy), was US\$ $11,049.41$, which accounted for $0.1 \%$ of the overall cost, and $0.3 \%$ of the total direct cost. Most of the cost of these services $(72 \%)$ accrued during consultation visits (US\$ 7,965.60), with the remaining services occurring during hospitalization (Table II and III). Hypertension was responsible for the greatest cost for allied health services at US\$ $8,521.03$. No allied health services were employed by patients who visited the hospital due to high cholesterol (Table II and III).

\section{Amount spent on diagnostic and treatment services}

The participants used several diagnostic services during 2006 and spent a total of US\$ $313,661.53$ (3\% of total overall cost, $8 \%$ of total direct cost). The greatest costs accrued were for breast cancer, coronary heart disease, hypertension and diabetes mellitus at US\$ $96,134.23$, US\$ 68,822.03, US\$ 67,462.78, and US\$ 42,239.03, respectively. High cholesterol was responsible for the least cost accrued due to diagnostic services at US\$ 15.18 (Table II). Most (90.3\%) of the cost of diagnostic procedures was accrued during hospitalization (Table III).

Treatment services accrued a cost of US\$ $1,109,142.18(12 \%$ of total overall cost and $30 \%$ of total direct cost). The greatest costs accrued were for breast cancer, diabetes mellitus, coronary heart disease, and colon cancer at US\$ 771,977.99, US\$110,877.59, US\$ 109,081.34, and US\$ 45,241.81, respectively (Table II). Treatment services were divided almost equally between consultations and hospitalizations (51\% and 49\%, respectively) (Table III).

\section{Indirect costs}

\section{Premature mortality}

The estimated cost of premature mortality was US\$ 95,309.00. Although deaths occur- red for both genders, this cost was estimated from the YPLL, and could only be computed for women because the mortality observed for males occurred beyond the age of 65 years. The diseases responsible for this cost were breast cancer at US\$ 72,355.00 (75.9\% cost of premature mortality) and hypertension at US\$ 22,954.00 (24.1\% cost of premature mortality) (Table IV).

\section{Permanent disability}

The total discounted cost of permanent disability was based on 38 patients and accrued a cost of US\$ 1,908,176.00 (28\% of total cost and $81 \%$ of total indirect cost). The comorbidities responsible for permanent disabilities were diabetes mellitus, hypertension, stroke and osteoarthritis, accruing discounted costs of US\$ 867,761.00, US\$ 206,087.00, US\$144,211.00, and US\$ 349,799.00, respectively (Table IV).

\section{Cost of temporary disability}

The total discounted cost of temporary disability in patients under 65 years who were not permanently disabled amounted to US\$ $39,899.10$ in lost productivity. Fifty-three percent of this loss was as a result of temporary disability in men. Temporary disability was responsible for $2 \%$ of the indirect cost and $0.7 \%$ of the total cost of the diseases studied (Table IV).

Coronary heart diseases accrued the greatest cost due to temporary disability followed by diabetes, hypertension, and colon cancer at US\$ 17,987.40 (45\%), US\$13,457.91 (34\%), US\$ 3,575.38 (9\%), and US\$ 2,859.76 (9\%), respectively (Table IV).

\section{Cost of absenteeism}

The total cost of absentee days was US\$ $229,175.56$. Women were responsible for $55.5 \%$ of overall losses due to absenteeism. The diseases that contributed the most to this cost were diabetes mellitus, hypertension, breast cancer and coronary heart disease at US\$ 70,505.28 (31\%), US\$ 54,819.30 (24\%), US\$ 40,174.64 (18\%), and US\$ 38,573.68 (17\%), respectively (Table IV).

\section{Overall costs}

The sum of the costs attributable to the diseases studied was US\$ 5,672,617.68. The four main contributors were diabetes mellitus (47.0\%), breast cancer (18.8\%), hypertension $(10.0 \%)$, and coronary heart disease $(9.6 \%)$. Female patients were responsible for $63.3 \%$ of the overall costs attributable to the diseases covered. However, being a woman was not found to be statistically associated with greater overall costs $(\mathrm{p}=0.44 ; \mathrm{CI}=95 \%)$. Female patients also accrued more than half 


\begin{tabular}{|c|c|c|c|c|c|}
\hline \multirow[b]{2}{*}{ Disease } & \multicolumn{5}{|c|}{ Indirect cost (US\$) } \\
\hline & $\begin{array}{c}\text { Premature } \\
\text { mortality }\end{array}$ & $\begin{array}{l}\text { Permanent } \\
\text { disability }\end{array}$ & $\begin{array}{l}\text { Temporary } \\
\text { disability }\end{array}$ & Absenteeism & Total [US\$ (\%)] \\
\hline \multicolumn{6}{|l|}{ DM } \\
\hline - Males & - & $583,331.00$ & $11,498.32$ & $36,565.14$ & $631,394.46(66.3)$ \\
\hline - Females & - & $284,430.00$ & $1,959.59$ & $33,940.14$ & $320,329.73(33.7)$ \\
\hline • Total & - & $867,761.00$ & $13,457.91$ & $70,505.28$ & $951,724.19(100)$ \\
\hline \multicolumn{6}{|l|}{ HTN } \\
\hline - Males & 0.00 & $65,369.00$ & $1,922.30$ & $28,447.05$ & $95,738.35$ (33.3) \\
\hline - Females & $22,954.00$ & $140,718.00$ & $1,653.08$ & $26,372.25$ & $191,697.33(66.7)$ \\
\hline • Total & $22,954.00$ & $206,087.00$ & $3,575.38$ & $54,819.30$ & $287,435.68(100)$ \\
\hline \multicolumn{6}{|l|}{ CHD } \\
\hline - Males & - & - & $6,180.19$ & $19,225.19$ & $25,405.38$ (44.9) \\
\hline - Females & - & - & $11,807.21$ & $19,348.49$ & $31,155.70(55.1)$ \\
\hline • Total & - & - & $17,987.40$ & $38,573.68$ & $56,561.08(100)$ \\
\hline \multicolumn{6}{|l|}{$\mathbf{s}$} \\
\hline - Males & - & $50,399.00$ & 328.07 & $8,656.35$ & $59,383.42$ (38.2) \\
\hline - Females & - & $93,812.00$ & 423.70 & $1,641.60$ & $95,877.30(61.8)$ \\
\hline • Total & - & $144,211.00$ & 751.77 & $10,297.95$ & $155,260.72(100)$ \\
\hline \multicolumn{6}{|l|}{ GD } \\
\hline - Males & - & - & - & $1,560.20$ & $1,560.20(58.3)$ \\
\hline - Females & - & - & - & $1,114.80$ & $1,114.80(41.7)$ \\
\hline • Total & - & - & - & $2,675.00$ & $2,675.00(100)$ \\
\hline \multicolumn{6}{|l|}{ BC } \\
\hline - Males & 0.00 & - & 0.00 & 0.00 & $0.00(0)$ \\
\hline - Females & $72,355.00$ & - & 27.34 & $40,174.64$ & $112,556.98(100)$ \\
\hline • Total & $72,355.00$ & - & 27.34 & $40,174.64$ & $112,556.98(100)$ \\
\hline \multicolumn{6}{|l|}{ CC } \\
\hline - Males & - & - & 0.00 & $7,135.54$ & $7,135.54(60.6)$ \\
\hline - Females & - & - & $2,859.76$ & $1,777.30$ & 4,637.06 (39.4) \\
\hline • Total & - & - & $2,859.76$ & $8,912.84$ & $11,772.60(100)$ \\
\hline \multicolumn{6}{|l|}{ OA } \\
\hline - Males & - & $133,233.00$ & $1,225.87$ & 163.08 & $134,621.95(38.0)$ \\
\hline - Females & - & $216,566.00$ & 0.00 & $2,845.27$ & $219,411.27(62.0)$ \\
\hline • Total & - & $349,799.00$ & $1,225.87$ & $3,008.35$ & $354,033.22(100)$ \\
\hline \multicolumn{6}{|l|}{ HC } \\
\hline - Males & - & - & 13.67 & 0.00 & $13.67(6.2)$ \\
\hline - Females & - & - & 0.00 & 207.52 & 207.52(93.8) \\
\hline • Total & - & - & 13.67 & 207.52 & $221.19(100)$ \\
\hline \multicolumn{6}{|c|}{ Economic burden } \\
\hline - Males & 0.00 & $832,332.00$ & $21,168.42$ & $101,752.55$ & $955,252.97(49.4)$ \\
\hline - Females & $95,309.00$ & $735,526.00$ & $18,730.68$ & $127,422.01$ & $976,987.69(50.6)$ \\
\hline - Total & $95,309.00$ & $1,567,858.00$ & $39,899.10$ & $229,175.56$ & $1,932,240.66(100)$ \\
\hline
\end{tabular}

Table IV. Breakdown of the total indirect costs of the diseases studied by gender (US\$)

$\mathrm{BC}=$ Breast Cancer, $\mathrm{CC}=$ Colon Cancer, $\mathrm{CHD}=$ Coronary Heart Disease, DM = Diabetes Mellitus, GD = Gallbladder Disease, $\mathrm{HC}=\mathrm{High}$ Cholesterol, $\mathrm{HTN}=$ hypertension, $\mathrm{OA}=$ osteoarthritis, $\mathrm{S}=$ Stroke

of the cost of all conditions studied except coronary heart disease (Table V). Total direct cost of the total burden of disease was US\$ $3,740,377.02(65.9 \%$ of total cost). About
$70 \%$ of direct cost was accrued by females (Table II and V). Women were not found to be statistically associated with greater direct costs $(\mathrm{p}=0.30 ; \mathrm{CI}=95 \%)$. Total indirect 


\begin{tabular}{|c|c|c|c|}
\hline Disease & $\begin{array}{l}\text { Direct costs } \\
\text { (US\$) }\end{array}$ & $\begin{array}{l}\text { Indirect costs } \\
\text { (US\$) }\end{array}$ & $\begin{array}{l}\text { Total costs } \\
\text { [US\$ }(\%)]\end{array}$ \\
\hline \multicolumn{4}{|l|}{ DM } \\
\hline - Males & $642,953.41$ & $631,394.46$ & $1,274,347.87(47.8)$ \\
\hline - Females & $1,071,660.86$ & $320,329.73$ & $1,391,990.59(52.2)$ \\
\hline • Total & $1,714,614.27$ & $951,724.19$ & $2,666,338.46(100)$ \\
\hline \multicolumn{4}{|l|}{ HTN } \\
\hline - Males & $129,234.77$ & $95,738.35$ & $224,973.12(39.5)$ \\
\hline - Females & $153,414.31$ & $191,697.33$ & $345,111.64(60.5)$ \\
\hline • Total & $282,649.08$ & $287,435.68$ & $570,084.76(100)$ \\
\hline \multicolumn{4}{|l|}{ CHD } \\
\hline - Males & $253,452.74$ & $25,405.38$ & $278,858.12(51.3)$ \\
\hline - Females & $233,323.08$ & $31,155.70$ & $264,478.78(48.7)$ \\
\hline - Total & $486,775.82$ & $56,561.08$ & $543,336.90(100)$ \\
\hline \multicolumn{4}{|l|}{$\mathbf{S}$} \\
\hline - Males & $38,068.81$ & $59,383.42$ & $97,452.23(41.0)$ \\
\hline - Females & $44,400.12$ & $95,877.30$ & $140,277.42(59.0)$ \\
\hline - Total & $82,468.93$ & $155,260.72$ & $237,729.65(100)$ \\
\hline \multicolumn{4}{|l|}{ GD } \\
\hline - Males & 764.25 & $1,560.20$ & $2,324.45(17.2)$ \\
\hline - Females & $10,070.09$ & $1,114.80$ & $11,184.89(82.8)$ \\
\hline - Total & $10,834.34$ & $2,675.00$ & $13,509.34(100)$ \\
\hline \multicolumn{4}{|l|}{ BC } \\
\hline - Males & 0.00 & 0.00 & $0.00(0)$ \\
\hline - Females & $952,998.65$ & $112,556.98$ & $1,065,555.63(100)$ \\
\hline - Total & $952,998.65$ & $112,556.98$ & $1,065,555.63(100)$ \\
\hline \multicolumn{4}{|l|}{ CC } \\
\hline - Males & $19,163.36$ & $7,135.54$ & $26,298.90$ (37.8) \\
\hline - Females & $38,635.57$ & $4,637.06$ & 43,272.63 (62.2) \\
\hline - Total & $57,798.93$ & $11,772.60$ & $69,571.53(100)$ \\
\hline \multicolumn{4}{|l|}{ OA } \\
\hline - Males & $19,682.62$ & $134,621.95$ & $154,304.57(33.6)$ \\
\hline - Females & $85,153.48$ & $219,411.27$ & $304,564.75(66.4)$ \\
\hline • Total & $104,836.10$ & $354,033.22$ & 458,869.32 (100) \\
\hline \multicolumn{4}{|l|}{$\mathrm{HC}$} \\
\hline - Males & $20,813.10$ & 13.67 & 20,826.77 (43.7) \\
\hline - Females & $26,587.80$ & 207.52 & 26,795.32(56.3) \\
\hline • Total & $47,400.90$ & 221.19 & $47,622.09(100)$ \\
\hline \multicolumn{4}{|c|}{ Economic burden } \\
\hline - Males & $1,124,133.06$ & $955,252.97$ & $2,079,386.03$ (36.7) \\
\hline - Females & $2,616,243.96$ & $976,987.69$ & 3,593,231.65 (63.3) \\
\hline - Total & $3,740,377.02$ & $1,932,240.66$ & $5,672,617.68(100)$ \\
\hline
\end{tabular}

Table V. Total cost of care for the diseases studied by gender (US\$)

$\mathrm{BC}=$ Breast Cancer, $\mathrm{CC}=$ Colon Cancer, $\mathrm{CHD}=$ Coronary Heart Disease, $\mathrm{DM}=$ Diabetes Mellitus, GD = Gallbladder Disease, HC = High Cholesterol, HTN = hypertension, $\mathrm{OA}=$ osteoarthritis, $\mathrm{S}=$ Stroke
$59.7 \%$ and $47.5 \%$ of the total direct and indirect costs, respectively.

\section{Total costs attributable to obesity}

In order to arrive at the costs attributable to obesity, the population attributable risk (PAR) for each disease due to obesity was calculated as outlined in the methodology (Table I). The resulting values were then applied to the cost of each disease.

The overall costs attributable to obesity for males and females were estimated at US\$ $271,921.28$ and US\$ 885,251.61, respectively, giving a total estimate of US\$ $1,157,172.89$. This figure does not include premature mortality since the level of premature mortality was very low and perhaps did not reflect the true mortality rate of the patients. Therefore, males and females contributed $23.5 \%$ and $76.5 \%$, respectively to the cost of obesity (Table VI). Women were not found to be statistically associated with greater obesity costs $(p=0.16 ; C I=95 \%)$. When the cost of breast cancer was removed from the cost of obesity, females accrued $74.6 \%$ of the cost $(p=0.23 ; C I=95 \%)$. Also, when both breast cancer and colon cancer costs were removed from the cost of obesity, females accrued $74.6 \%$ of the cost $(p=0.23$; $\mathrm{CI}=95 \%$ ).

\section{DISCUSSION}

This is a cost-of-illness study in which data analysed were collected from the hospital records of 554 patients who were treated at the University Hospital of the West Indies during 2006 for obesity-related diseases, thereby arriving at an estimate of the direct and indirect costs of obesity. This method is considered more accurate than using prevalence data for the estimation of cost because, in such methodologies, all patients with the same malady are treated as a homogenous group while patients with similar diagnoses may have vastly different treatment experiences and costs. The present study did not include the costs of pain and suffering [54], or presenteeism (reduced performance while at work due to ill health) [55].

This study estimated the economic burden attributable to the nine diseases of interest to be US\$ 5,672,617.68 for the patients studied. The three main contributors were diabetes mellitus, breast cancer and hypertension, with female patients being responsible for $63.3 \%$ of the overall costs. However, there is a potential for bias towards females due to the failure to include a principal male cancer (e.g., prostate cancer), where there is growing evidence of a relationship with obesity [56]. 
Female patients also accrued more than half of the cost of all diseases studied except for coronary heart disease. This is contrary to expectation given that females accounted for $60 \%$ of the cases studied. The higher direct cost for female patients is due to their unique presentation in breast cancers which also bore the highest direct cost.

Total direct and indirect costs attributable to the nine diseases of interest were estimated at US\$3,740,377.02 and US $\$ 1,932,240.66$, respectively for men and women. Women accrued $70 \%$ of direct costs and $51 \%$ of indirect costs but also represented $60 \%$ of the study population. The total per capita direct costs for men and women were US\$ 5,109.70 and US $\$ 7,833.07$, respectively. The total per capita indirect costs for men and women were US\$ 4,342.06 and US\$ 2,925.11, respectively. Given the higher prevalence of obesity among Jamaican women [5], they seemed to have been managing their conditions better than the men, with lower indirect costs. Their conditions could have been more easily managed with drugs while the men needed more diagnostic and treatment interventions. When breast cancer cases were excluded, women accrued $60 \%$ of direct and $48 \%$ of indirect costs. The greatest contributors to direct cost were prescription drugs followed by treatment services at US\$ 2,245,245.10 and US $\$ 1,109,142.18$, respectively. The greatest contributors to indirect cost were permanent disability followed by the absenteeism at US\$ $1,567,858.00$ and US\$ 229,175.56, respectively.

The overall cost of obesity was estimated at US\$ $1,157,172.89$ ( $20 \%$ of total overall cost for the diseases studied), with females contributing $77 \%$ of the overall cost of obesity. Excluding breast cancer, the female contribution to the cost of obesity falls to $75 \%$. This estimate did not include premature mortality due to the inadequacy of data: although mortality occurred for both genders, the mortality observed for males occurred beyond the age of 65 years and thus could not be included in the calculation of YPLL. Thus, YPLL could only be computed for women. For all diseases, females contributed more than $50 \%$ to the cost of obesity. In a previous study of 8 diseases (not including breast and colon cancer), females contributed to $55 \%$ of the overall cost of obesity [57], which is lower compared to our data when these two cancers are excluded.

Diabetes contributed the most to the cost of obesity at US\$ 557,775.44 (48\%), followed by osteoarthritis, hypertension, and breast cancer at US\$2 $21,719.43$ (19\%), US\$ $169,540.90(15 \%)$, and US\$ 85,244.45 (7\%),

\begin{tabular}{lccc}
\hline \multirow{2}{*}{ Diseases } & \multicolumn{3}{c}{ Cost (US\$) } \\
\cline { 2 - 4 } & Males & Females & Total [US\$ (\%)] \\
\hline DM & $140,178.27$ & $417,597.18$ & $557,775.44(48.2)$ \\
HTN & $31,496.24$ & $138,044.66$ & $169,540.90(14.7)$ \\
CHD & $13,942.91$ & $29,092.67$ & $43,035.58(3.7)$ \\
S & $8,770.70$ & $29,458.26$ & $38,228.96(3.2)$ \\
GD & 139.46 & $5,256.89$ & $5,396.35(0.5)$ \\
BC & - & $85,244.45$ & $85,244.45(7.4)$ \\
CC & $4,207.82$ & $15,145.42$ & $19,353.24(1.7)$ \\
OA & $69,437.06$ & $152,282.37$ & $221,719.43(19.2)$ \\
HC & $3,748.82$ & $13,129.71$ & $16,878.53(1.4)$ \\
Economic & $271,921.28(23.5)$ & $885,251.61(76.5)$ & $1,157,172.89(100)$ \\
burden & & & \\
{$[$ US\$ (\%)] } & & & \\
\hline
\end{tabular}

Table VI. Cost attributable to obesity for the diseases studied $\mathrm{BC}=$ Breast Cancer, $\mathrm{CC}=$ Colon Cancer, $\mathrm{CHD}=$ Coronary Heart Disease, $\mathrm{DM}=$ Diabetes Mellitus, GD = Gallbladder Disease, $\mathrm{HC}=$ High Cholesterol, HTN = hypertension, $\mathrm{OA}=$ osteoarthritis, $\mathrm{S}=$ Stroke

respectively. The PAR of obesity in diabetes is not disproportionate when compared to the PAR of obesity in the other diseases. In a study that estimated direct costs of obesity for a group of diseases that did not include osteoarthritis, the 3 largest contributors to the costs were hypertension, type 2 diabetes mellitus and coronary artery disease [51]. In another study that estimated costs of obesity for a group of diseases (osteoarthritis excluded), coronary artery disease, type 2 diabetes mellitus and hypertension were among the 4 largest contributors to the costs [38]. Therefore, the results are comparable with type 2 diabetes mellitus and hypertension being among the top 4 contributors.

Cardiovascular disease has been predicted to be the leading cause of death and disability worldwide by 2020 [58]. However, the leading cause of permanent disability in this study was diabetes mellitus. In this study, the two contributors to mortality were hypertension and breast cancer, with an estimated cost of US\$22,954.00 and US\$ 72,355.00 respectively. Mortality is however projected to increase dramatically from ischemic heart disease in developing countries by 2020 [59]. In previous studies, cerebrovascular diseases, heart diseases, hypertensive diseases, diabetes mellitus, and malignant neoplasms have been found to be among the ten leading causes of death in Jamaica $[36,60]$.

\section{CONCLUSIONS}

This study has shown the high cost of CNCDs, with diabetes accruing the highest cost overall as well as the highest cost attributable to obesity. On a per capita basis, 
females accrued greater costs of illness for gallbladder disease (US\$ 33.49 vs. US\$ 10.57 about three times that of the males) and osteoarthritis (US\$ 911.87 vs. US\$ 701.38). On a per capita basis, males accrued higher costs of illness for diabetes mellitus (US\$ $5,792.49$ vs. US\$ 4,167.64), coronary heart disease (US\$ $1,267.54$ vs. US\$ 791.85) and high cholesterol (US\$ 94.67 vs. US\$ 80.23). On a per capita basis, males and females accrued similar costs of illness for hypertension (US\$ 1,022.61 vs. US\$ 1,033.27), stroke (US\$ 442.96 vs. US\$ 419.99), and colon cancer (US\$ 119.54 vs. US\$ 129.56). Overall, on a per capita basis, males and females accrued similar costs of illness (US\$ 9,451.75 vs. US\$ 10,758.18).

Obesity was responsible for $20.4 \%$ of total overall cost of the diseases studied. With respect to the cost of illness due to obesity, on a per capita basis, females accrued greater costs of illness for all of the diseases studied: diabetes mellitus (US\$ 1,250.29 vs. US\$ 637.17, twice than males), hypertension (US\$ 413.31 vs. US\$ 143.16, about three times than males), coronary heart disease (US\$ 87.10 vs. US\$ 63.38), stroke (US\$ 88.20 vs. US\$ 39.87, more than twice than males), gallbladder disease (US\$ 15.74 vs. US\$ 0.63 , twenty-five times than males), colon cancer (US\$ 45.35 vs. US\$ 19.13, more than twi- ce than males), osteoarthritis (US\$ 455.94 vs. US\$ 315.62), and hypercholesterolemia (US\$ 39.31 vs. US\$ 17.04, more than twice than males). In addition, females accrued $77 \%$ of the cost of illness due to obesity with them accruing a higher per capita cost than males (US\$ 2,650.45 vs. US\$ 1,236.01 twice than males).

This study showed that although Jamaica is not an affluent country, obesity and its comorbidities are important sources of economic burden. This is therefore further argument that chronic non-communicable diseases are not necessarily diseases of affluence. In addition, this study indicated that although Jamaica is in a public health transition, obesity is already showing a strong impact on medical and economic costs to the country. In general, policies to control and prevent CNCDs should seek to improve lifestyle behavior activities (diet and physical activity) of both men and women, if these indicators are to improve. Jamaica could include in its planning for the future, the training of health personnel (particularly physicians, dieticians and nutritionists) in the management and prevention of obesity. As the demographic transition continues and the population ages, the economic costs will become unsurmountable if efforts to arrest this trend do not begin.

\section{REFERENCES}

1. Omran AR. The epidemiologic transition. A theory of the epidemiology of population change. Milbank Mem Fund Q 1971; 49: 509-8; http://dx.doi.org/10.2307/3349375

2. World Health Organization. Global Health Risks: Mortality and burden of disease attributable to selected major risks. Geneva: WHO Press, 2009

3. Yusuf S, Reddy S, Ônpuu S, et al. Global Burden of Cardiovascular Diseaes: Part I: General Considerations, the Epidemiologic Transition, Risk Factors, and Impact of Urbanization. Circulation 2001; 104: 2746-53; http://dx.doi. org/10.1161/hc4601.099487

4. World Health Organization Global InfoBase team. The SuRF Report 2. Surveillance of chronic risk factors: Countrylevel data and comparable estimates. Geneva: WHO Press, 2005

5. Wilks R, Younger N, Tulloch-Reid M, et al. Jamaica Health and Lifestyle Survey 2007-8. TECHNICAL REPORT. Epidemiology Research Unit, Tropical Medicine Research Institute, University of the West Indies, Mona, 2008

6. Guh DP, Zhang W, Bansback N, et al. The Incidence of Co-morbidities Related to Obesity and Overweight: A systematic review and meta-analysis. BMC Public Health 2009; 9; http://dx.doi.org/10.1186/1471-2458-9-88

7. World Health Organization. Obesity and Overweight factsheet from the WHO. Available at: http://www.who.int/ mediacentre/factsheets/fs311/en (last accessed May 2016)

8. Bray G. Medical Consequencies of Obesity. J Clin Endocrinol Metab 2004; 89: 2583-9; http://dx.doi.org/10.1210/ jc. 2004-0535

9. Field A, Coakley E, Must A, et al. Impact of Overweight on the Risk of Developing Common Chronic Diseases During a 10-Year Period. Arch Intern Med 2001; 161: 1581-6; http://dx.doi.org/10.1001/archinte.161.13.1581

10. Must A, Spadano J, Coakley EH, et al. The Disease Burden Associated with Overweight and Obesity. JAMA 1999; 282: 1523-9; http://dx.doi.org/10.1001/jama.282.16.1523 
11. Colditz G, Willet W, Ronitzky A, et al. Weight Gain as a Risk Factor for Clinical Diabetes Mellitus in Women. Ann Intern Med 1995; 122: 481-6; http://dx.doi.org/10.7326/0003-4819-122-7-199504010-00001

12. Caribbean Commission on Health and Development. Report of the Caribbean Commission on Health and Development. Ian Randle Publishers, 2006

13. Sasai H, Sairenchi T, Iso H, et al. Relationship between Obesity and Incident Diabetes in Middle-aged and Older Japanese Adults: The Ibaraki Prefectural Health Study. Mayo Clin Proc 2010; 85: 36-40; http://dx.doi.org/10.4065/ mcp. 2009.0230

14. Cassano P, Rosner B, Vokonas P, et al. Obesity and Body Fat Distribution in Relation to the Incidence of Noninsulin-dependent Diabetes Mellitus. A prospective Cohort Study of Men in the Normative Aging Study. Am J Epidemiol 1992; 136: 1474-86

15. Tulloch-Reid MK, Hanson RL, Williams DE, et al. Do Measures of Body Fat Distribution Provide Information on the Risk of Type 2 Diabetes in Addition to Measures of General Obesity? Diabetes Care 2003; 26: 2556-61; http:// dx.doi.org/10.2337/diacare.26.9.2556

16. Vazquez G, Duval S, Jacobs Jr. DR, et al. Comparison of Body Mass Index, Waist Circumference, and Waist/Hip Ratio in Predicting Incident Diabetes: A meta-analysis. Epidemiol Rev 2007; 29 : 115-28; http://dx.doi.org/10.1093/ epirev/mxm008

17. Stampfer MJ, Maclure KM, Colditz GA, et al. Risk of syptomatic gallstones in women with severe obesity. Am J Clin Nut 1992; 55: 652-8

18. Tsai CJ, Leitzmann MF, Willett WC, et al. Prospective study of abdominal adiposity and gallstone disease in US men. Am J Clin Nut 2004; 80: 38-44

19. Okosun IS, Cooper RS, Rotimi CN, et al. Association of Waist Circumference with Risk of Hypertension and Type 2 Diabetes in Nigerians, Jamaicans, and African Americans. Diabetes Care 1998; 21: 1836-42; http://dx.doi. org/10.2337/diacare.21.11.1836

20. Girotto E, de Andrade SM, Cabrera MA. Prevalence of Abdominal Obesity in Hypertensive Patients Registered in a Family Health Unit. Arq Bras Cardio 2010; 94: 754-62; http://dx.doi.org/10.1590/S0066-782X2010005000049

21. Wamala JF, Karyabakabo Z, Ndungutse D, et al. Prevalence factors associated with Hypertension in Rukungiri District, Uganda - A Community-based Study. Afr Health Sci 2009; 9: 153-60

22. de Koning L, Merchant A, Pogue JA. Waist circumference and waist-to-hip ratio as predictors of cardiovascular events: meta-regression analysis of prospective studies. Eur Heart J 2007; 28: 850-6; http://dx.doi.org/10.1093/ eurheartj/ehm026

23. Rexrode KM, Carey VJ, Hennekens CH, et al. Abdominal Adiposity and Coronary Heart Disease in Women. JAMA 1998; 280: 1843-8; http://dx.doi.org/10.1001/jama.280.21.1843

24. Rexrode KM, Buring JE, Manson JE. Abdominal and total adiposity and risk of coronary heart disease in men. Int J Obese 2001; 25: 1047-56; http://dx.doi.org/10.1038/sj.ijo.0801615

25. Gelber RP, Gaziano JM, Orav EJ, et al. Measures of Obesity and Cardiovascular Risk among Men and Women. $J$ Am Coll Cardio 2008; 52: 605-15; http://dx.doi.org/10.1016/j.jacc.2008.03.066

26. Owen CG, Whincup PH, Orfei L, et al. Is body mass index before middle age related to coronary heart disease risk in later life? Evidence from observational studies. Int J Obese 2009; 33: 866-77; http://dx.doi.org/10.1038/ijo.2009.102

27. Hubert HB, Feinleib M, McNamara PM, et al. Obesity as an independent risk factor for cardiovascular disease: A 26-year follow-up of participants in the Framingham Heart Study. Circulation 1983; 67: 968-77; http://dx.doi. org/10.1161/01.CIR.67.5.968

28. Zhang X, Shu X-O, Gao Y-T, et al. General and Abdominal Adiposity and Risk of Stroke in Chinese Women. Stroke 2009; 40: 1098-104; http://dx.doi.org/10.1161/STROKEAHA.108.539692

29. Walker SP, Rimm EB, Ascherio A, et al. Body size and fat distribution as predictors of stroke among US men. Am J Epidemiol 1996; 144: 1143-50; http://dx.doi.org/10.1093/oxfordjournals.aje.a008892

30. Suk S-H, Sacco RL, Boden-Albala B, et al. Abdominal Obesity and Risk of Ischemic Stroke: The Nothern Manhattan Stroke Study. Stroke 2003; 34: 1586-92; http://dx.doi.org/10.1161/01.STR.0000075294.98582.2F

31. Kurth T, Gaziano JM, Berger K, et al. Body Mass Index and the Risk of Stroke in Men. Arch Intern Med 2002; 162: 2557-62; http://dx.doi.org/10.1001/archinte.162.22.2557

32. Kurth T, Gaziano JM, Rexrode KM, et al. Prospective Study of Body Mass Index and Risk of Stroke in Apparently Health Women. Circulation 2005; 111: 1992-8; http://dx.doi.org/10.1161/01.CIR.0000161822.83163.B6 
33. Hu D, Hannah J, Gray RS, et al. Effects of Obesity and Body Fat Distribution on Lipids and Lipoproteins in Nondiabetic American Indians: The Strong Heart Study. Obes Res 2000; 8: 411-21; http://dx.doi.org/10.1038/oby.2000.51

34. Gostynski M, Gutzwiller F, Kuulasmaa K, et al. Analysis of the relationship between total cholesterol, age, body mass index among males and females in the WHO MONICA Project. Int J Obese 2004; 28: 1082-90; http://dx.doi. org/10.1038/sj.ijo.0802714

35. Steyn K, Sliwa K, Hawken S, et al. Risk Factors Associated with Myocardial

36. Infarction in Africa: The INTERHEART Africa Study. Circulation 2005; 3554-61

37. McCaw-Binns A, Holder Y, Spence K, et al. Multisource method for determining mortality in Jamaica: 1996 and 1998. Department of Community Health \& Psychiatry, University of the West Indies. International Biostatistics Information Services. Division of Health Promotion \& Protection, Ministry of Health, Jamaica. Statistical Institute of Jamaica. 2002

38. Abdulkadri AO, Cunningham-Myrie C, Forrester T. Economic Burden of Diabetes and Hypertension in CARICOM States. Social and Economic Studies 2009; 58: 175-97

39. Colditz GA. Economic Costs of Obesity. Am J Clin Nut 1992; 55: 503S-7S

40. Wolf AM, Colditz GA. Current Estimates of the Economic Cost of Obesity in the United States. Obes Res 1998; 6: $97-106$

41. Finkelstein EA, Fiebelkorn IC, Wang G. National Medical Spending Attributable to Overweight and Obesity: How Much and Who's Paying? Health Aff 2003; 219-26

42. Wilson PW, D’Agostino RB, Sullivan L, et al. Overweight and Obesity as Determinants of Cardiovascular Risk. The Framingham Experience. Arch Intern Med 2002; 162: 1867-72; http://dx.doi.org/10.1001/archinte.162.16.1867

43. Statistical Institute of Jamaica. End of Year Population by Age and Sex: 2009, 2009. Available at: http://www. statinja.gov.jm/EndofYearPopulationbyAgeandSex2008.aspx

44. Barcelo' A, Aedo C, Rajpathak S, et al. The Cost of Diabetes in Latin America and the Caribbean. Bull World Health Organ 2003; 81: 19-27

45. Prüss-Üstün A, Mathers C, Corvalán C, et al. Introduction and methods: assessing the environmental burden of disease at national and local levels. Geneva: World Health Organization, 2003

46. PAHO. Techniques to Measure the Impact of Mortality: Years of Potential Life Lost. Epidemiol Bull 2003; 24: 1-16

47. The Tripartite Meeting of Experts on Labour Statistics. Updating the International Standard Classification of Occupations (ISCO-88). Geneva, 2007

48. Jamaica Employers' Federation. Salary and Benefits Survey for Cheif Executive Officers, Executives and Managers. Kingston: Jamaica Employers' Federation (JEF), 2009

49. Jamaica Employers' Federation. Salary and Benefits Survey for Technical and Professional Staff, Supervisory, Clerical, and Hourly-rated Employees. Kingston: Jamaica Employers' Federation (JEF), 2009

50. Mattke S, Balakrishnan A, Bergamo G, et al. A Review of Methods to Measure Health-related Productivity Loss. Am J Manag Care 2007; 13: 211-17

51. Flor LS, Campos MR, de Oliveira AF, et al. Diabetes burden in Brazil: fraction attributable to overweight, obesity, and excess weight. Rev Saúde Publican 2015; 49: 1-10; http://dx.doi.org/10.1590/S0034-8910.2015049005571

52. Birmingham CL, Muller JL., Palepu A, et al. The Cost of Obesity in Canada. CMAJ 1999; 160: 483-8

53. de Oliveira ML, Santos LMP, da Silva EN. Direct Healthcare Cost of Obesity in Brazil: An Application of the Cost-of-Illness Method from the Perspective of the Public Health System in 2011 PLoS ONE 2015; 10: e0121160; http://dx.doi.org/10.1371/journal.pone.0121160

54. Arnold M, Pandeya N, Byrnes G, et al. Global burden of cancer attributable to high body-mass index in 2012: a population-based study. Lancet Oncol 2015; 16: 36-46; http://dx.doi.org/10.1016/S1470-2045(14)71123-4

55. Cooper BS, Rice DP. The economic cost of illness revisited. Soc Secur Bull 1976; 39: 21-36

56. Zakrzewska K. Presenteeism - Unhealthy Extra Presence in the Workplace. Przegl Epidemiol 2014; 68: 77-80

57. Fowke JH, Motley SS, Concepcion RS, et al. Obesity, body composition, and prostate cancer. BMC Cancer 2012; 12: 23 ; http://dx.doi.org/10.1186/1471-2407-12-23

58. Oster G, Edelsberg J, O'Sullivan AK, et al. The Clinical and Economic Burden of Obesity in a Managed Care Setting. Am J Manag Care 2000; 6: 681-9 
59. Levenson JW, Skerrett PJ, Gaziano JM. Reducing the global burden of cardiovascular disease: The role of risk factors. Prev Cardio 2002; 5: 188-99; http://dx.doi.org/10.1111/j.1520-037X.2002.00564.x

60. Leeder S, Raymond S, Greenberg H, et al. A Race Against Time: The Challenge of Cardiovascular Disease in Developing Economies. New York: The Center for Global Heath and Economic Development, 2004

61. Cruz A, ed. Health in the Americas, 2007. Washington, D.C.: Pan American Health Organization, 2007, pp. 448-64 